\title{
MONITORING OF LANDSLIDE ACTIVITY IN SLOVAKIA TERRITORY USING MULTI-TEMPORAL INSAR TECHNIQUES
}

\author{
Bakon, M. ${ }^{(1,2)}$, Papco, J. ${ }^{(1)}$, Perissin, D. ${ }^{(3)}$, Lazecky, M. ${ }^{(2,4)}$, Sousa, J. J. ${ }^{(2,5)}$, Hlavacova, $\mathbf{I}^{(2,6)}$, Batorova, K. $^{(7)}$, \\ Ondrejka, . $^{(8)}$, Liscak, P. $^{(8)}$, Paudits, P. $^{(8)}$, Real, $N .^{(9)}$ \\ (1) Department of Theoretical Geodesy, Slovak University of Technology, Radlinskeho 11, 81368 Bratislava, Slovakia, \\ www.insar.sk, Email: matus.bakon@stuba.sk,juraj.papco@stuba.sk \\ (2) Universidade de Trás-os-Montes e Alto Douro, UTAD, Quinta de Prados, 5000-801 Vila Real, Portugal, Email: \\ jjsousa@utad.pt \\ (3) School of Civil Engineering, Purdue University, 550 Stadium Mall Drive, West Lafayette, IN47907, Office: HAMP \\ 4106, USA,www.sarproz.com,Email:perissin@purdue.edu \\ (4) IT4Innovations, VSB-TU Ostrava, 17. listopadu 15, 70800 Ostrava-Poruba, Czech Republic, E-mail: \\ milan.lazecky@vsb.cz \\ (5) INESC TEC - INESC Technology and Science (formerly INESC Porto), E-mail: jjsousa@utad.pt \\ (6) Czech Technical University in Prague, Faculty of Civil Engineering, Thákurova 7, 16629 Praha 6, Czech Republic, \\ Email: hlavacova@insar.cz \\ (7) Department of Engineering Geology, Faculty of Natural Sciences, Comenius University in Bratislava, Mlynska \\ dolina, 84215 Bratislava 4, Pavilon G, Slovakia,Email: batorovak@fns.uniba.sk \\ ${ }^{(8)}$ State Geological Institute of Dionýz Štúr, Mlynská dolina 1, 81704 Bratislava, Slovakia, www.geology.sk, E-mail: \\ peter.ondrejka@geology.sk, pavel.liscak@geology.sk, peter.paudits@geology.sk \\ (9) Consultores de Engenharia Norvia, SA Vila Real, Portugal,www.norvia.pt, Email: n.real@norvia.pt
}

\begin{abstract}
Slope deformations are the most important geohazards in Slovakia which annually cause an extensive economic damage of significant influence. About 22000 slope deformations have been registered so far, covering an area of almost $2600 \mathrm{~km}^{2}$. Since 2010, 639 new slope failures have been witnessed and their activation was driven mainly by the climatic anomalies such as extraordinary rainfalls. Many of these landslides currently represent a direct threat to the lives, health and property of the residents in the affected areas. The landslide Nizna Mysla is considered to be the second most catastrophic landslide in the history of Slovakia. Damages to buildings and engineering networks had not been identified in the ' 90 s of the last century when the first problems with the slope stability appeared. Up-tonow monitoring techniques has currently been reassessed to account for the results from satellite Synthetic Aperture Radar (SAR) techniques.
\end{abstract}

\section{INTRODUCTION}

Nizna Mysla is a densely populated municipality that rest exclusively upon active landslides. The most disastrous landslide occurred early morning on $4^{\text {th }}$ of June, 2010 just after heavy rainfalls. Three active landslides originated within the former dormant one with a several earth blocks inclined downslope below the main scarp in the central part of the village. The biggest landslide appeared in the southern part of the village and damaged 40 houses, local roads (Fig. 1), water and gas pipelines, sewage and electrical lines. The area was evacuated and more 29 houses had to be demolished to date because of the strong rate of

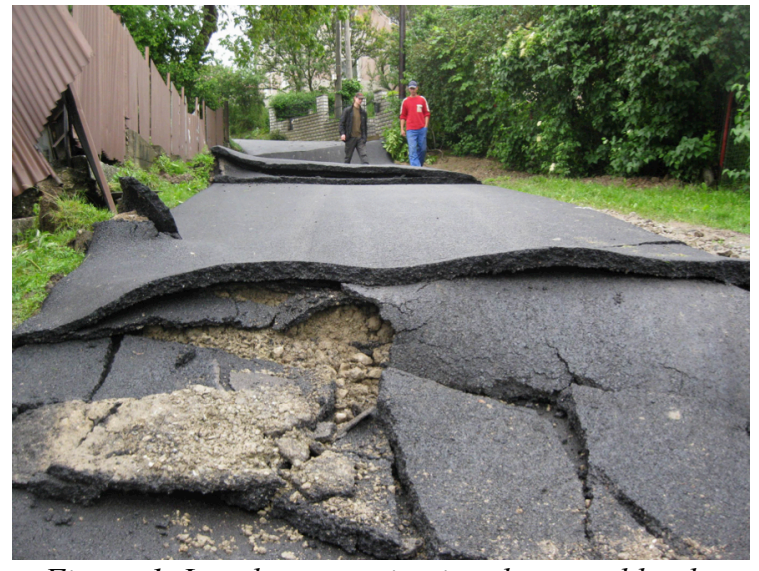

Figure 1. Local communication destroyed by the Nizna Mysla landslide [1]

disruption and static problems. The dimensions of this complex landslide are $410 \mathrm{~m}$ (length) and $1810 \mathrm{~m}$ (width). The average slope angle ranges between $6^{\circ}-$ $7^{\circ}$. The height of the striking and uneven main scarp is about $5-7 \mathrm{~m}$. According to the landslide morphology and inclinometric measurements, the depth of a basal slip surface is estimated to be between 12 and $15 \mathrm{~m}$. The velocity of the mass movement was assumed to reach several centimetres per year [2], making it challenging to detect by satellite radar techniques.

\section{GEOLOGICAL BACKGROUND}

The landslide is situated within Kosicka kotlina Depression (Fig. 2) on the so-called Varhanovce ridge. The depression is filled with the Neogene sedimentary rocks ranging in age from the Carpathian to Pannonian 
as well as by the volcanic rocks of Sarmatian to Early Pannonian. The southernmost part of the north-south oriented Varhanovce ridge is built of grey silty and calcareous clays and siltstones with intercalations of redeposited rhyolite tuffs and tuffites [3]. These rocks are covered by deluvial clays with angular fragments of weathered tuffs and siltstones (up to $10-15 \%$ ) and locally also by fills up to $2 \mathrm{~m}$ thickness. The Varhanovce ridge separates alluvial plains of Hornad and Olsava rivers.

The fault system of north-south orientation has played a very important role by forming the Kosicka kotlina Depression. One fault is running through the Hornad river valley and is connected with seismic activity of the Kosice area. At the eastern part of the Kosice town the earthquake with macroseismic observed intensity of $7^{\circ}$ EMS-98 (European Macroseismic Scale) was recorded in 1676 [4].

\section{SYNTHETIC APERTURE RADAR ANALYSIS}

For this case study, four different approaches have been utilized: i) standard Persistent Scatterer Interferometric SAR (PSInSAR) analysis where velocities are evaluated applying a linear trend model; ii) PSInSAR analysis with non-linear model for deformation estimates; iii) Quasi-PSInSAR analysis for retrieving information from partially coherent targets; iv) amplitude analysis in order to detect structures affected by a huge deformation process; all of them implemented in SARPROZ software [5]. Analyses were carried out on the set of Single Look Complex (SLC) images using different SAR satellites. The methods and datasets utilized for this research are summarized in Table 1.

\begin{tabular}{|c|c|c|c|c|c|}
\hline Satellite & Track & Pass & Images & Period & Method \\
\hline ERS & 136 & Desc. & 43 & $\begin{array}{c}1992- \\
1999\end{array}$ & $\begin{array}{l}\text { PSInSAR, } \\
\text { Quasi- } \\
\text { PSInSAR }\end{array}$ \\
\hline \multirow[t]{2}{*}{$\mathbf{E N V}^{1}$} & 329 & Asc. & 32 & $\begin{array}{c}2003- \\
2010\end{array}$ & $\begin{array}{c}\text { PSInSAR, non- } \\
\text { linear } \\
\text { PSInSAR, } \\
\text { amplitude } \\
\text { analysis }\end{array}$ \\
\hline & 408 & Desc. & 32 & $\begin{array}{c}2002- \\
2010\end{array}$ & $\begin{array}{l}\text { PSInSAR, non- } \\
\text { linear } \\
\text { PSInSAR, } \\
\text { amplitude } \\
\text { analysis }\end{array}$ \\
\hline $\mathbf{A L S}^{2}$ & 621 & Asc. & 2 & 2010 & DInSAR \\
\hline
\end{tabular}

Processing was performed on a local scale (approx. 2x2 $\mathrm{km}^{2}$ ) allowing for neglecting the atmospheric perturbations as the correlation distance of Atmospheric Phase Screen (APS) is less than few kilometers [6]. Moreover, focusing on small areas allows for achieving higher accuracy in displacements estimation and,

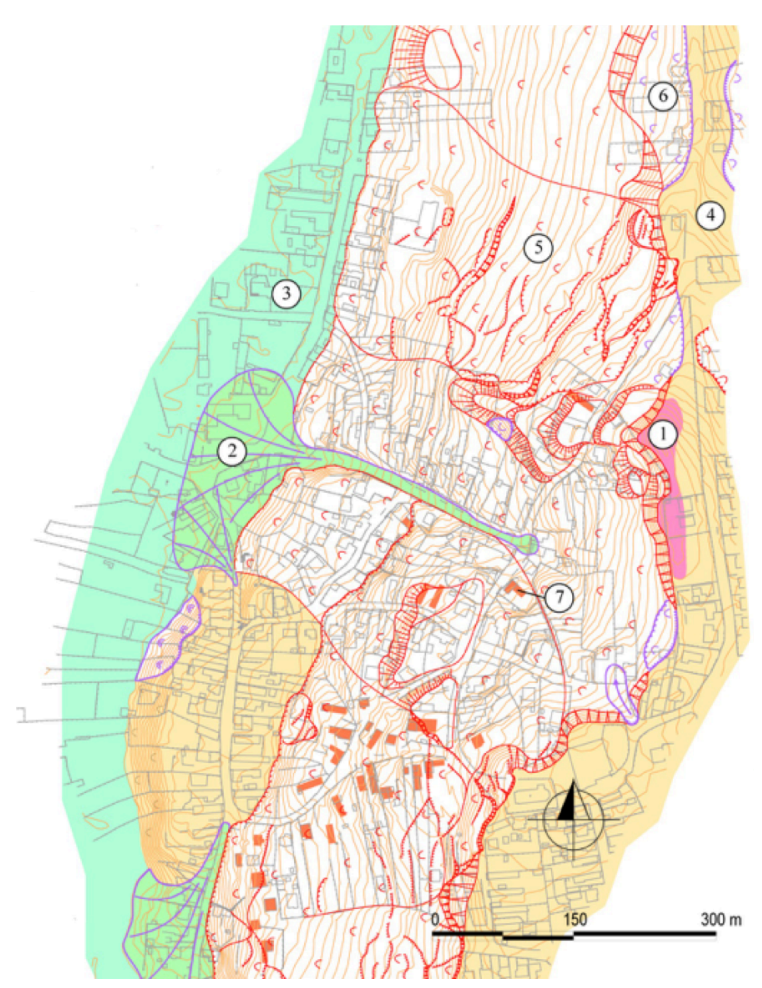

Figure 2: Geological setting of the Nizna Mysla landslide. 1) clays, claystones with horizons of sand, gravel and tuff (Neogene), 2) proluvial sediments (Quaternary), 3) river flood plain sediments (Quaternary), 4) deluvial sediments (Quaternary), 5) landslide deluvia - active landslides, 6) landslide deluvia - potential landslides, 7) demolished and damaged buildings (compiled according to [7])

especially, to detect non liner trends. It is worth noting that non-linear movements are sometimes crucial [8] for a suitable investigation of the landslide processes. Since non-linear movements are expected to have smaller correlation in space, it is possible to detect such movements via low pass filter in the time domain. Furthermore, loosen the restrictive conditions imposed by the original PSInSAR technique [9] through exploiting Quasi-PSInSAR approach [10] it is possible to increase spatial density of the targets. The target height and displacement are estimated here in the targetdependent subset of interferograms that could be generated by different images' graph connections in order to choose the one that best fits the estimate requirements.

\subsection{Standard PS InSAR processing}

Within the standard PSInSAR processing [9], persistent scatterer candidates were chosen by applying threshold value on Amplitude Stability Index. The common reference point for each dataset was used and was selected in the stable areas outside of the landslide boundaries that were measured during emergency works in 2012 [7]. For the selected points, height and displacement were estimated and deformation time series were reconstructed. The standard PSInSAR 

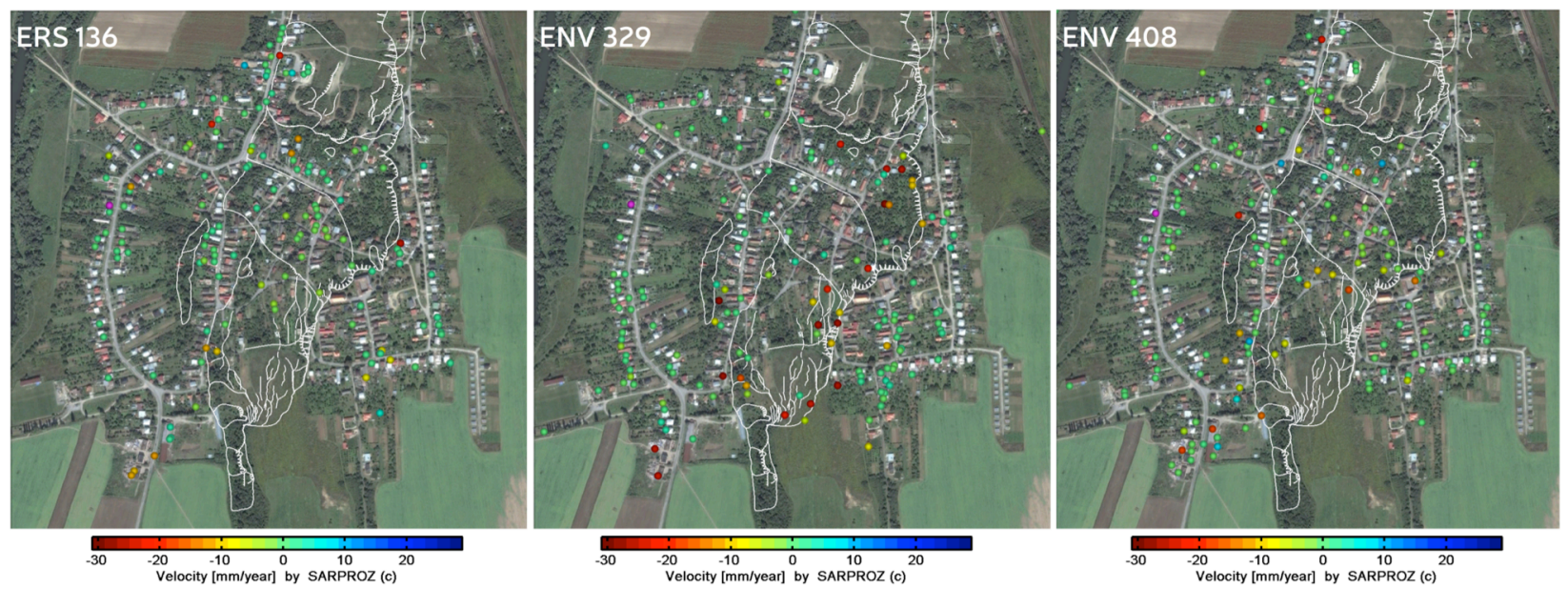

Figure 3: Deformation maps of Nizna Mysla with points coloured proportionally to the estimated line-of-sight velocities, superimposed on the landslide boundary map (white) with the location of common reference point (purple).

approach with the linear model assumption for the deformation estimates showed that the investigated urban area of Nizna Mysla was prone to subsidence of up to $-30 \mathrm{~mm} / \mathrm{year}$ in the whole monitoring period of ERS and ENVISAT (1992 - 2010). The majority of PS points that exhibits subsiding motion are located within the landslide boundaries (Fig. 3).

\subsection{Linear vs. non-linear deformation time series}

Expanding the standard PSInSAR model to account for a non-linear deformation component, it is possible to discover various types of movements that remain undetectable by linear approach. In the case of ENVISAT's observations (2002-2010), these movements may correspond to the landslide activation process. From the time series in Fig. 4, changes on some structures were observable since 2009 and shortly before the most disastrous landslide on $4^{\text {th }}$ of June, 2010 .
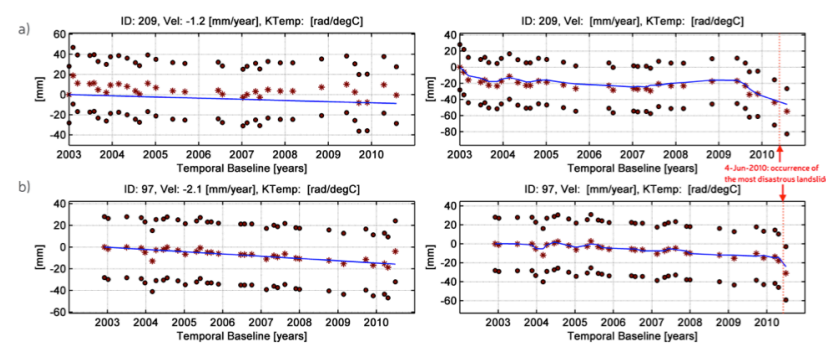

Figure 4: Time series of the line-of-sight displacement from ENVISAT's a) ascending and b) descending track.

\subsection{Quasi-PSInSAR}

Extracting the information also from partially coherent targets [10] in order to increase the spatial coverage of the velocity estimates and exploiting complete ERS images' graph to maximize the information to be extracted, reveals the extents of the area prone to instability early between $1992-1999$ (Fig. 5). These extents matches with the most affected areas.

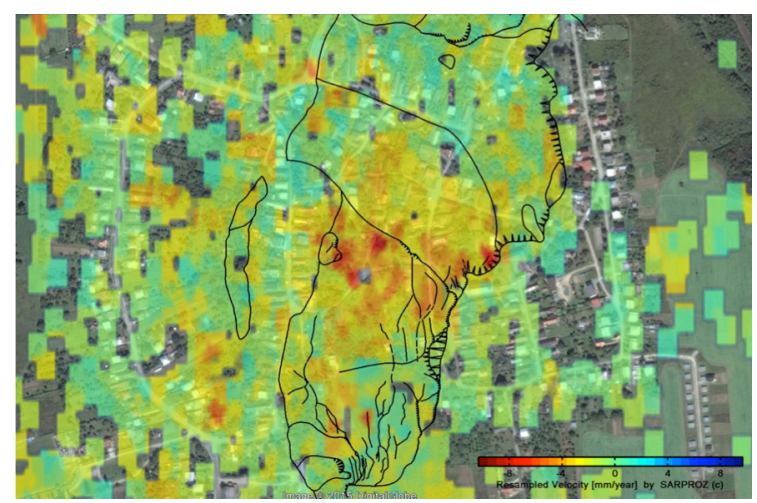

Figure 5: Deformation map from Quasi-PSInSAR analysis superimposed on the landslide boundary map (black).

\subsection{Amplitude analysis}

One of the inspection tools that could help to identify the structures affected by the strong deformation process, causing radar scatterers to lose their stable phase behavior, is the amplitude analyzed as the function of time [11]. By modeling the amplitude time series, it is possible to detect changes that couldn't be quantified within PSI approach. In Fig. 6, depicted is the building demolished due to its disrupted static. 

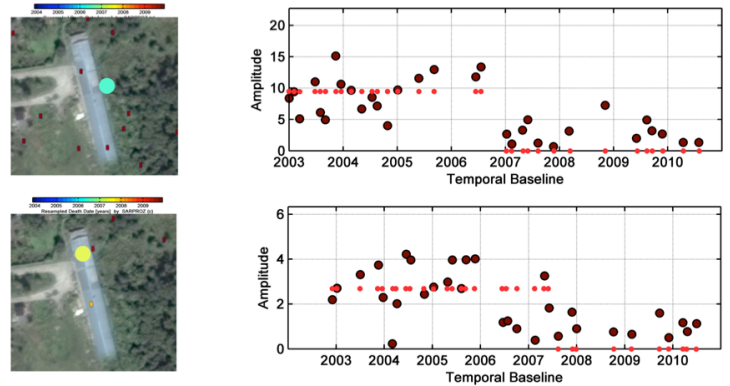

Figure 6: Right) The so called on-off model (dots) of the amplitude time series (circles) is showing death dates of the radar scatterers with their location (left) and color proportional to the year when the radar return becomes weaker.

\subsection{Differential InSAR}

Several slopes were suspected of deformation with higher rates then those possibly detectable by middleresolution C-band data. For this reason, the ALOS Lband data were utilized. Differential interferogram in Fig. 7, spanning the period from 26-Jun-2010 to 11May-2010 with perpendicular baseline of $52.4 \mathrm{~m}$ is showing the spatial changes that occurred during main slip on 4-Jun-2010. Unwrapped interferometric phase indicates areas with the highest relative displacement. Further analysis of ALOS data is ongoing.

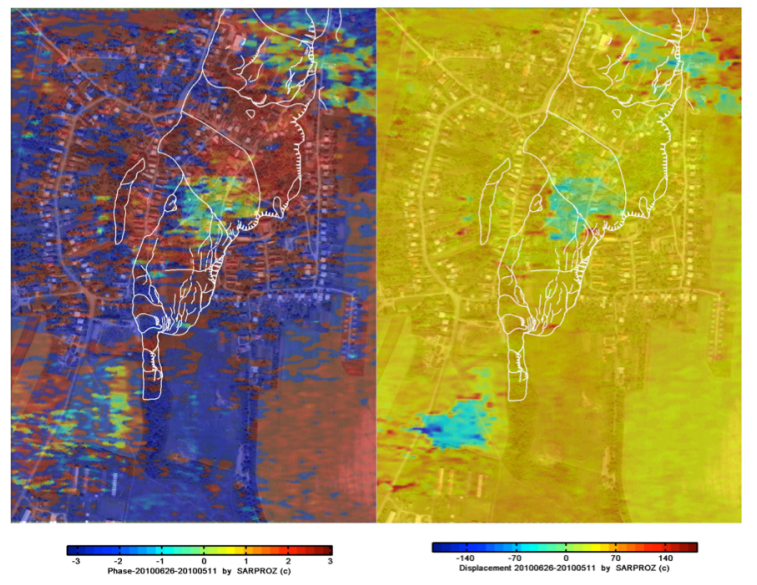

Figure 7: Left) Differential interferogram 26-Jun2010 - 11-May-2010 and, right) unwrapped displacement [mm] superimposed on landslide boundaries map (white).

\section{CONCLUSION AND FUTURE WORK}

In this work, different satellite radar interferometry techniques are presented, including Differential InSAR, classical PSInSAR technique, PSInSAR with non-linear model for the deformation estimates, Quasi-PSInSAR and amplitude analysis in order to test the possibilities of different inspection methods to obtain information about the movements that can preceded landslide activation process in Nizna Mysla village (Slovakia) on $4^{\text {th }}$ of June, 2010. The applied techniques appear to be promising for serving useful information not only before land sliding processes endanger public safety and during emergency works, but also for updating of an existing landslide inventory maps aimed at proper urban planning. Beside the line-of-sight decomposition process for the retrieval of horizontal and vertical components of the deformation phenomena, multitemporal ALOS processing will be applied in further. Since the ground survey of the landslide was carried out in several phases from 2010 to 2014 (Fig. 8) after main slip, and no satellite data are covering this period, the comparison with parallel ground truth data was not possible. The ground survey of the landslide consisted of almost 80 boreholes to depths of $5-25 \mathrm{~m}$ located in

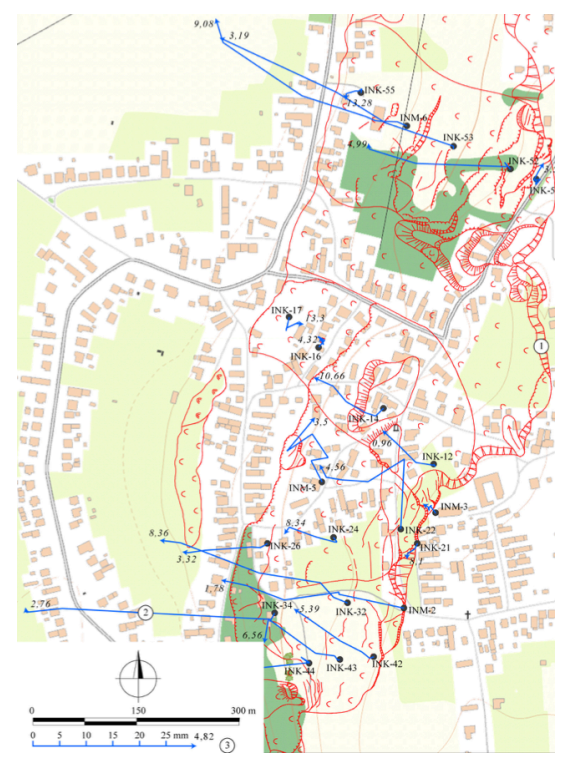

Figure 8: Movement activity along shear planes detected by precision inclinometry. 1 - limits of landslide area (head scarp), 2 - vector of measured deformation, 3 - magnitude of deformation recorder from December 5, 2011 till November 13, 2013, with indication of measurement depth (modified after [7]; topographic groundwork - ZBGIS ${ }^{\circledR}$ )

the most damaged parts of the village (Fig. 8) that are visible also in ALOS DInSAR interferograms (Fig. 7) and will be re-assessed by multi-temporal processing. The stability condition in these areas is studied by regular measurements based on the observations of groundwater level depth changes, geodetic and inclinometric measurements and regular evaluation of climatic factors [12]. With already ongoing SENTINEL-1 mission and free accessible near-real time data archive, the future work will be focused on the setting of the possible precursors for the slope failures in order to estimate the landslide risks using benefits of satellite radar interferometry. 


\section{ACKNOWLEDGEMENTS}

This contribution was created with the support of the Ministry of Education, Science, Research and Sport of the Slovak Republic within the Research and Development Operational Programme for the project "University Science Park of STU Bratislava", ITMS 26240220084, co-funded by the European Regional Development Fund. The work is supported by the The National Centre of Earth's Surface Deformation Diagnostic in the area of Slovakia, ITMS 26220220108 under the Research and Development Operational Programme funded by the ERDF and the grant No. 1/0642/13 of Slovak Grant Agency VEGA. The project is also supported by the European Fund for Regional Progress - FEDER (Fundo Europeu de Desenvolvimento Regional) through the project BI/COMPETE/38732/UTAD/2014 entitled "RemotWatch - Alert and Monitoring System for Physical Structures". This paper has been elaborated in the framework of the project New creative teams in priorities of scientific research, reg. no. CZ.1.07/2.3.00/30.0055, supported by the Operational Programme Education for Competitiveness and cofinanced by the European Social Fund and the state budget of the Czech Republic. Data for the project were provided by ESA within the C1.P projects 28760 Monitoring of slope instability in various areas in the world and 9981 Detection of ground deformation using radar interferometry techniques. Data have been processed by SARPROZ (Copyright (c) 2009-2015 Daniele Perissin) and visualised in Matlab ${ }^{\circledR}$ using Google Maps $^{\mathrm{TM}}$ and Google Earth $^{\mathrm{TM}}$. Authors are grateful to US Geological Survey for making the SRTM 1 Arc-Second Global DEM data available for the processing.

\section{REFERENCES}

1. Brček, M. (2010). Local communication destroyed by the Nizna Mysla landslide (Photo)

2. Petro, L', Jánová, V., Žilka, A., Ondrejka, P., Liščák, P., Balík, D., 2014: Catastrophic landslide in Nižná Myšl'a Village (Eastern Slovakia). In: K. Sassa, P. Canuti \& Y. Yin (Eds.) „Landslide Science for a Safer Geoenvironment", Vol. 3 Targeted Landslides, 305-311. Publ. Springer, Switzerland. ISBN 978-3-319-04995-3, DOI 10.1007/978-3319-04996-0

3. Kaličiak, M. (ed.), Baňacký, V., Janočko, J., Karoli, S., Petro, L., Spišák, Z., Vozár, J., Žec, B., Ivanička, J., Vass, D., 1996: Geological map of the Slanské vrchy Mts. and Košická kotlina depression - southern part 1:50 000. Pub. GS SR, Bratislava.

4. Procházková, D., Brouček, I., Guterch, B. \& Lewandowska-Marciniak, H., 1978: Map and list of the maximum observed macroseismic intensities in Czechoslovakia and Poland. Publ. Inst. Geophys., Pol. Acad. Sc., B-3 (122), 3-75.

5. Perissin, D. (2015) SARPROZ software. Official Product Web Page:. http://www.sarproz.com

6. Hanssen, R. (2001). Radar interferometry, data interpretation and error analysis. Kluwer Academic Publishers.

7. Sláma, M., Gomolčák, M., Komoň, J., Turovský, F., Tunega, O., Mišove, P., Bačo, J., Vrábl'ová, K. \& Pastierik, S. (2012) Nižná Myšl’a - sanácia havarijného zosuvu - I. etapa, sanácia geologického prostredia, odborný geologický dohl'ad. - I. etapa, sanácia geologického prostredia. (Nižná Myšl'a - corrective measures at emergency landslide, first stage). Geokontakt, s.r.o. Košice. Manuskript. Archív Št. Geol. Úst. D. Štúra, Bratislava, 55 p. (In Slovak)

8. Bozzano, F., Esposito, C., Franchi, S., Mazzanti, P., Perissin, D., Rocca, A., Romano, E. (2014). Analysis of a Subsidence Process by Integrating Geological and Hydrogeological Modelling with Satellite InSAR Data. Engineering Geology for Society and Territory - Volume 5, Springer International Publishing Switzerland, pp. 155-159

9. Ferretti, A., Prati, C., and Rocca, F. (2001). Permanent scatterers in SAR interferometry. IEEE Transactions on Geoscience and Remote Sensing, 39(1):8-20.

10. Perissin, D. and Wang, T. (2012). Repeat-Pass SAR Interferometry with Partially Coherent Targets, IEEE Transactions on Geoscience and Remote Sensing, vol. Volume 50, p. Pages 271-280.

11. Perissin, D. and Ferretti, A. (2007). Urban target recognition by means of repeated spaceborne SAR images, IEEE Transactions on Geoscience and Remote Sensing, Volume 45, Issue 12, Pages: 4043 - 4058 .

12. Liščák, P., Ondrejka, P., Šimeková, J., Petro, L., Pauditš, P., Žilka, A., Mašlárová, I., Iglárová, L., Wagner, P., Madarás, J., 2014: Recent emergency landslides in Slovakia. Geologické práce, správy, 125 , in press. 